\title{
Morphometric Relationships among the Clariid Fishes of the Lake Victoria Basin, Tanzania
}

\author{
Chacha John Mwita \\ Department of Aquatic Sciences and Fisheries, College of Natural and Applied Sciences, University of Dar es \\ Salaam, Dar es Salaam, Tanzania \\ Email: mwitachacha@udsm.ac.tz
}

Received 13 October 2014; revised 8 November 2014; accepted 4 December 2014

Copyright (C 2015 by author and Scientific Research Publishing Inc.

This work is licensed under the Creative Commons Attribution International License (CC BY). http://creativecommons.org/licenses/by/4.0/

c) (7) Open Access

\begin{abstract}
Six hundred and fifty-eight specimens of the Clariidae were collected from seven localities in the Lake Victoria basin and the Malagarasi wetland, Tanzania. A total of three hundred unadjusted morphometric measurements and meristic counts were analysed with the aim of assessing the adequacy of morphometric technique to delineate the clariid species occurring in the Lake Victoria basin. Results showed that morphometrics augmented by multivariate analysis (PCA, DCA and cluster analysis) amalgamated the clariid fishes into three groups, the Clarias alluaudi/C. werneri, C. gariepinus/C. liocephalus and Clariallabes petricola. Although other workers have used this technique, the present study concluded that, standing alone morphometrics is not a substitute for external morphology in the identification of clariid fish species, as it failed to separate the clariids into their respective taxonomic species. The technique, however, insinuates the regressional morphological relationships among the clariids occurring in the Lake Victoria basin.
\end{abstract}

\section{Keywords}

Morphology, Regression, Clariids, Lake Victoria

\section{Introduction}

The external morphology of the family Clariidae is characterized by an elongated body with a long dorsal fin. An adipose fin is present in Heterobranchus species [1]. According to [2] the dorsal and anal fins are distinctly separated from the caudal fin in C. gariepinus and C. liocephalus, whereas in $C$. werneri and $C$. alluaudi the dorsal and anal fins end very close to the caudal fin. The large species of Clarias attain lengths of up to $1.5 \mathrm{~m}$ 
and have a large depressed head with a wide mouth [2] [3]. The head bears small eyes and four pairs of barbels [2]. The anterior and posterior fontanels, remnants of foetal characteristics, are present in most clariid species and form an important taxonomic feature [2]. Clarias gariepinus has a grey mottled colouration; C. liocephalus is reddish, while C. werneri and C. alluaudi are more or less blackish in appearance (pers. observation). The clariids have a wide global distribution; however, their greatest diversity occurs in continental Africa. They are also found in Syria, Southern Turkey and Southeast Asia [3].

Based on the external morphology, the clariid fishes can be ordered in a series of an increasing eel-like form [1]. For the species found in the Lake Victoria basin and the Malagarasi River system, H. longifilis is positioned at the beginning of the series in view of its fusiform body with a well-developed adipose fin [2]. Clariallabes petricola from the Lake Victoria has extreme anguilliform body morphology. Clariallabes petricola has the dorsal, anal and caudal fins merged to form a long confluent fin. The intermediate species, Clarias alluaudi and Clarias werneri are considered synonymous in view of their close similarity in external morphology [2].

The external features of the clariids have long been used to differentiate species in the family. For instance, serration of the pectoral fin spine, shape and position of the anterior fontanelle relative to the position of the eyes, and the position of dorsal and anal fins relative to the caudal fin, are some of the main characteristics used to differentiate the clariid species [2] [4]. Nevertheless the classification of the clariids based on this system has a number of shortcomings. For example, description of Clarias liocephalus Boulenger, 1898 by [4] is different from that of [2]. Eccles (opp. Cit) also regards Clarias werneri Boulenger, 1906 as a synonym of Clarias alluaudi Boulenger, 1906. Hence the need for an alternative identification scheme based on, for example, a combination of characters such as morphometric measurements and meristic counts. Such a technique was used by [5] on the moor frogs (Rana arvalis), [6] on the small barbs (Barbus humilis and B. trispilopleura) [7] and [8]. The aim of the present study was to utilize morphometric data to delineate the clariids species of Lake Victoria and assess the adequacy of this technique species.

\section{Materials and Methods}

\subsection{Study Site}

Lake Victoria, the largest tropical lake in the world, is shared between Tanzania, Uganda and Kenya (Figure 1). The lake lies in a shallow continental sag between the two arms of the Great Rift Valley, $1170 \mathrm{~m}$ above sea level. The lake has a maximum depth of $84 \mathrm{~m}$, a volume of $2750 \mathrm{~km}^{3}$, and a surface area of $68,800 \mathrm{~km}^{2}$. Primary inflows to the basin include rivers such as the Kagera in the west and the Mara in the east. However, over $90 \%$ of the annual water input to the basin depends mainly on direct rainfall, which is almost entirely balanced by evaporation. All outflows are to the north along the Nile through Lake Kyoga. The mean surface temperature is about $25^{\circ} \mathrm{C}$ while the temperature of deeper layers is about 1 to 2 degrees lower [4]. The choice of the study sites reflects the diversity of environments inhabited by different clariid fishes e.g. muddy vegetated lake margins (Clarias spp.), deep waters (Xenoclarias sp.) and river mouth and wetlands (Clariallabes sp.) [2].

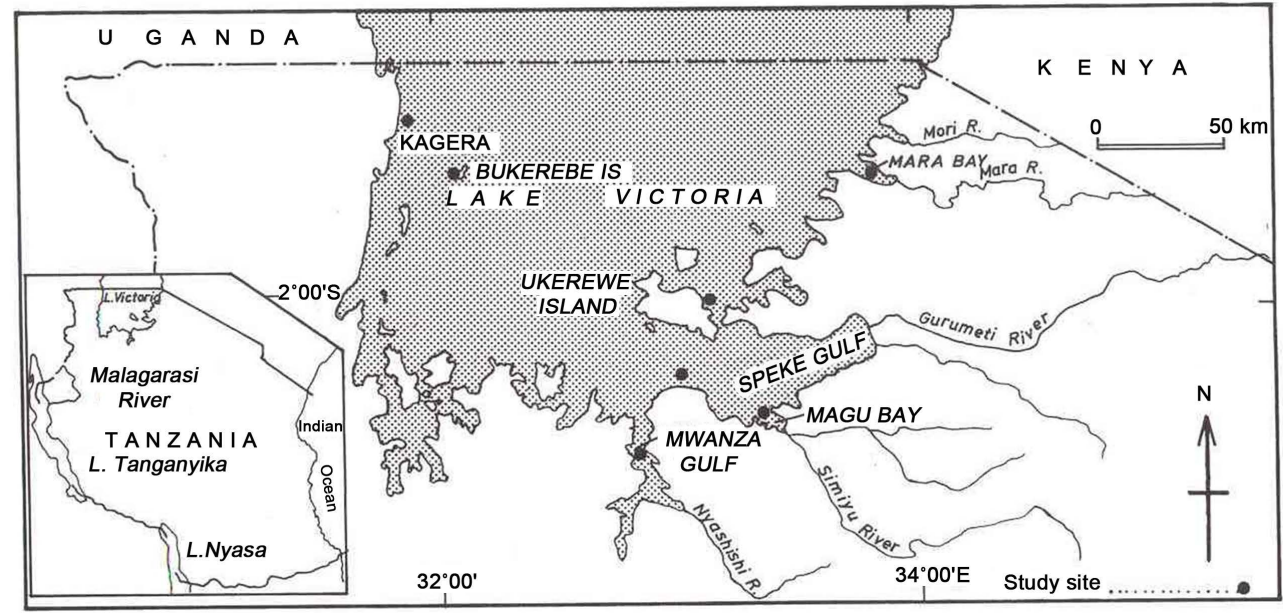

Figure 1. Lake Victoria basin fish sampling sites. 


\subsection{Methods}

\subsubsection{Collection of Fish and Identification}

Fish were caught by handlines and longlines with baited hooks, scoop nets and gills nets and transported in ice coolled boxes to the laboratory at TAFIRI Mwanza centre for identification, morphometric measurements and meristic counts. Fish species were identified based on phenotypic characteristics [2] [4] [9].

\subsubsection{Morphometric Measurements}

A total of twenty-seven morphometric measurements and six meristic counts were made on one side of the body of each fish specimen [10]. The following dimensions (see Figure 2) were measured from point to point using digital callipers under a low power $(10 \times)$ magnifier: total length $\left(\mathrm{L}_{\mathrm{T}}\right)$, standard length $\left(\mathrm{L}_{\mathrm{s}}\right)$, head length $(\mathrm{HL})$, head depth (HD), snout length (SnL), orbit diameter (OD), preanal length (PAL), vent to tail length (VTL), dorsal fin base length (DFL), anal fin base length (AFL), caudal peduncle length (CPL), dorsal caudal peduncle length (DCPL), ventral caudal peduncle length (VCPL), maximum body depth (BD), head width (HW), upper jaw length (UJ), lower jaw length (LJ), predorsal length (PDL) and prepelvic length (PPL), anterior fontanelle width (AFnW) and posterior fontanelle width (PFnW). Counts were also made of all segmented rays as: dorsal fin rays (dfr), anal fin rays (afr), caudal fin rays (cfr), pelvic fin rays (pfr), pectoral fin rays (ptfr) and vertebrae (vert).

\subsubsection{Data Analysis}

A total of three hundred unadjusted morphometric measurements and meristic counts from seven different populations of the clariids were analysed by Principal Component Analysis (PCA) [5]. The effect of size was removed by scaling all measurements as proportions of standard length $\left(\mathrm{L}_{\mathrm{S}}\right)$ of each fish except HD, HW, SnL, UJ, LJ and OD, which were scaled as proportions of HL. The VCPL, CPD, DFL and AFL were scaled as proportions of DCPL. Cluster analysis was carried out to generate dendrogram depicting the morphological relationship among the clariids based on morphometric measurements.

\section{Results}

Generally the result revealed that the clariids body depth (BD), head depth (HD) and caudal peduncle depth (CPD) decreased from Heterobranchus longifilis, Clarias gariepinus, Clarias alluaudi, Clarias werneri, Clarias liocephalus and Clariallabes petricola in that order. Similarly, the dorsal and ventral caudal peduncle lengths tended to diminish as the dorsal and anal fins get closer to the caudal fin.

Shape differences between the clariid fishes were analysed by PCA using unadjusted morphometric measurements. Length measurements for various body parts (TL, TS, PAL, VTL, PDL, PPL, HL, DFL, and AFL) showed positive loadings for PC 1, hence this component represented differences in body lengths. PC 1 explained $92.1 \%$ of the total variance. $99.3 \%$ of the total variance was explained by as many as four principal components. HD, HW, UJ, LJ, AfnL, CPD, CPL, DCPL, VCPL showed positive loading for PC 2 and PC 4. These two components therefore explained about the shape of the fish, and PC 3 explained differences in meristic counts (Table 1).

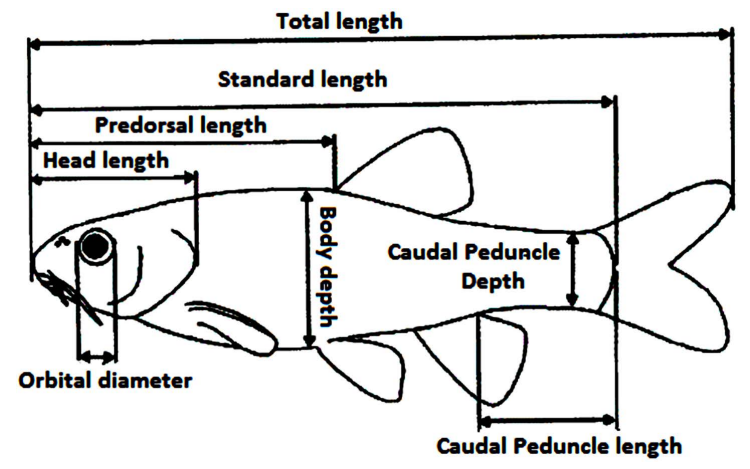

Figure 2. Illustration of some of the morphometric measurements taken. 
Table 1. Factor scores for the principal component analysis.

\begin{tabular}{|c|c|c|c|c|}
\hline Parameter & PC 1 & PC 2 & PC 3 & PC 4 \\
\hline $\mathrm{TL}$ & 3.13 & 0.53 & -1.46 & -0.51 \\
\hline TS & 2.70 & 0.27 & -0.92 & 0.08 \\
\hline PAL & 0.72 & 0.68 & -1.42 & 0.10 \\
\hline VTL & 1.58 & -0.14 & -0.04 & -0.24 \\
\hline $\mathrm{BD}$ & -0.37 & -0.07 & -0.56 & -0.07 \\
\hline PDL & 0.24 & 0.58 & -0.72 & -0.08 \\
\hline PPL & 0.59 & 0.59 & -1.20 & -0.12 \\
\hline PFL & -0.77 & 0.06 & -0.12 & 0.32 \\
\hline PtFL & -0.72 & 0.06 & -0.10 & 0.36 \\
\hline HL & 0.02 & 0.39 & -0.60 & 0.36 \\
\hline HD & -0.51 & 0.17 & -0.27 & 0.14 \\
\hline SnL & -0.64 & 0.15 & -0.14 & 0.29 \\
\hline OD & -0.78 & 0.07 & -0.11 & 0.31 \\
\hline HW & -0.31 & 0.19 & -0.32 & -0.13 \\
\hline UJ & -0.51 & 0.32 & -0.53 & 0.29 \\
\hline LJ & -0.57 & 0.26 & -0.47 & 0.13 \\
\hline AFnW & -0.78 & 0.04 & 0.01 & 0.37 \\
\hline AFnL & -0.64 & 0.16 & -0.19 & 0.33 \\
\hline PFnW & -0.79 & 0.03 & 0.06 & 0.38 \\
\hline PFnL & -0.75 & 0.03 & 0.14 & 0.38 \\
\hline DCPL & -0.75 & 0.33 & -0.34 & 0.20 \\
\hline DFL & 1.42 & -0.25 & 2.39 & 3.34 \\
\hline AFL & 0.87 & -0.72 & 1.87 & 1.92 \\
\hline CPD & -0.62 & 0.38 & -0.14 & 0.35 \\
\hline CPL & -0.74 & 0.38 & -0.25 & 0.16 \\
\hline VCPL & -0.75 & 0.19 & -0.64 & -0.09 \\
\hline ADFL & 0.12 & -4.13 & -0.83 & -1.48 \\
\hline $\mathrm{dfr}$ & 0.69 & 0.13 & 2.72 & -2.53 \\
\hline afr & 0.02 & 1.94 & 1.87 & -1.56 \\
\hline $\mathrm{cfr}$ & -0.54 & 0.62 & 0.25 & -0.57 \\
\hline ptfr & -0.66 & -0.46 & 0.14 & -0.01 \\
\hline vert & -0.06 & -2.67 & 0.59 & -0.87 \\
\hline Eigen Values & 276.25 & 14.06 & 6.36 & 1.12 \\
\hline$\%$ Total Variance & 92.08 & 4.68 & 2.12 & 0.37 \\
\hline Cumm. Eigenv & 276.25 & 290.31 & 296.67 & 297.79 \\
\hline Cumm. \% & 92.08 & 96.77 & 98.89 & 99.26 \\
\hline
\end{tabular}


The following clariids, C. gariepinus, C. liocephalus, C. werneri and C. alluaudi formed clear groups which, were separated from $B$. docmac, $H$. longifilis and Clariallabes petricola along PC 1 axis. PC 2 axis separated the clariids into two major groups. The upper group contained C. gariepinus/C. liocephalus group, whereas the lower group had C. alluaudi and C. werneri (Figure 3). When the effect of size was removed, all clariid fishes separated as a group from the $B$. docmac along PC 1 . The results of the Discriminant analysis of the unadjusted morphometric data supported those of PCA. DC 1 explained about 6.5\% for the adjusted measurements and only $4.7 \%$ for unadjusted measurements, $54.5 \%$ of the total variance were explained by as many as four Discriminant components; hence the discriminative power of the DCA to segregate the clariid fishes was low as opposed to that of the PCA.

\section{Discussion}

The genus Clarias has four species in the Lake Victoria basin; these are C. gariepinus, C. liocephalus, C. werneri and C. alluaudi [4], which, are classified, based on phenotypic appearance [2]. Clarias gariepinus is easily identified due to its mottled grey colouration and its large size (Max. $1.5 \mathrm{~m}$ ). Smaller and young C. gariepinus however, are difficult to identify based on phenotypic characteristics. The pectoral fin spine is serrated on the outer side only; this character however, is shared by other species in the genus.

Clarias liocephalus has been defined as having the pectoral fin spine serrated only on the outer side [2] and on both sides with the inner serration directed upward [9]. The present study only recorded the latter characteristic, i.e. as by [9]. However, serrations on the inner side were few (maximum of 8) and were easily torn off when removing tissues from the spine [11]. It is possible that [2] might have inadvertently scratched off the inner serrations during cleaning of tissues from the spine. This however depended on the sample size examined before reaching the conclusion.

Furthermore, $C$. liocephalus specimens examined in the present study had a phenotypic feature not reported by neither [9] nor [2]. The tips of the dorsal, anal and caudal fins have a narrow pale band. The pale band together with the serration of the pectoral fin spine on both sides indicate a strong resemblance to Clarias theodorae Borodin, 1936 [11], a species not known to occur in Lake Victoria. Clarias theodorae was reported from Lakes Tanganyika, Nyasa and the Rufiji River basin [2] [11]. However, the present material of C. liocephalus differs from $C$. theodorae in that both the dorsal and anal fins are distinct from the caudal fin. In $C$. theodorae, the dorsal and anal fins end very close to the caudal fin reducing both the dorsal caudal peduncle and the ventral caudal peduncle lengths close to zero. Comparing these specimens to those from the Rufiji River basin, it is possible that the specimen from the Lake Victoria basin is C. liocephalus with the pale band to the tips of the dorsal, anal and caudal fins as indicated by [11] but not reported by either [2] or [9] in their work.

Clarias werneri and C. alluaudi are difficult to differentiate by the external morphology. In both species the pectoral fin spine is serrated on both sides. The two species are only differentiated by the shape and location of

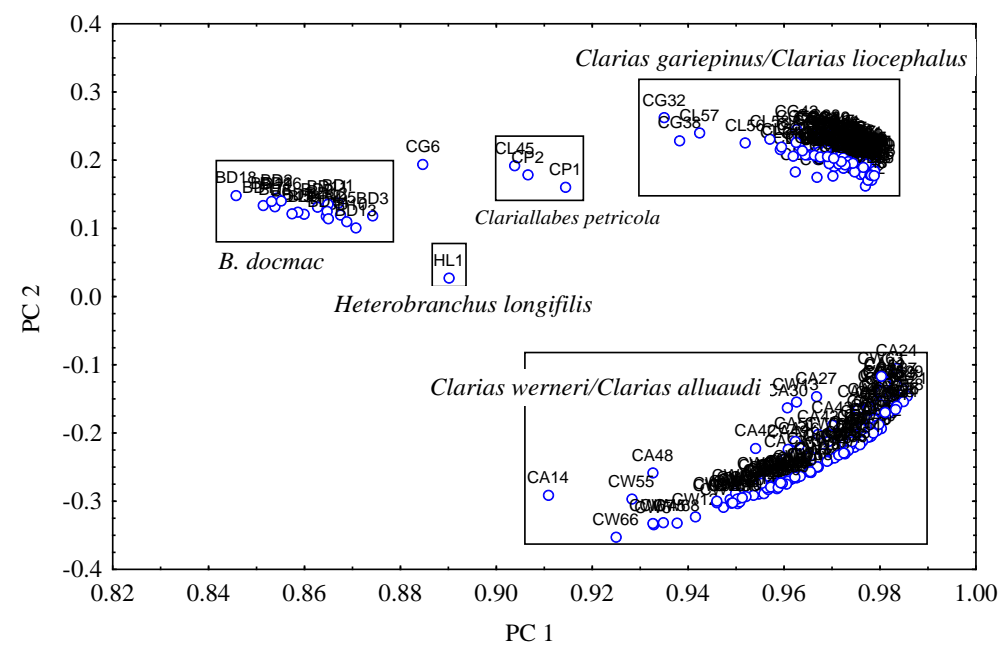

Figure 3. Scatter plot of size-dependent PC 1 and PC 2 scores for the clariid fish species from the Lake Victoria basin. 
the anterior fontanelle relative to the position of the eyes. In C. alluaudi, the fontanelle is sharply pointed and starts in front of the eyes, whereas the same is blunt and starts between the eyes in $C$. werneri. This however, is only increasingly evident in larger specimen.

PCA results showed that host size and body shape characterized by various parameters are the determining factors in morphometric identification. In the present study, PC 2 that relates to the shape of the fish separated the genus Clarias into two groups: The first group comprises C. gariepinus and C. liocephalus and the second group was that of $C$. werneri and C. alluaudi. The two groups are distinct in shape; for instance in the first group of $C$. gariepinus/C. liocephalus quantitative morphometric measurements indicated that pre-anal length, which is also a component of PC 2, is more than $50 \%$ of the standard length. In the second group of C. alluaudi/C. werneri, the distance from snout to anal fin is less than $50 \%$ of standard length.

Cluster analysis separated Clarias gariepinus into two clades in between the two clades of $C$. liocephalus. Molecular evidence [12] has revealed that C. gariepinus occurs in a number of genetically distinct groups, which, was further confirmed by [13]. C. gariepinus and C. liocephalus, on the other hand, differed in phenotypic appearance; in terms of colour for instance C. gariepinus is grey-mottled while C. liocephalus is tinged red. The pectoral fin spine in C. gariepinus is serrated on the outer side alone, whereas the same is serrated on both the inner and outer sides in C. liocephalus. These characters however, were not included in the cluster analysis.

The second group of $C$. alluaudi/C. werneri generated by PCA did not separate into definite groups but clustered sparsely. Close examination of the results showed that the sparsely distributed $C$. werneri and $C$. alluaudi were similar morphologically. Both species are more darkish in appearance and their pectoral fin spines are serrated on the inner and outer sides. The two species occupy more or less similar habitats and share certain feeding behaviour [4]. [2] suggested that these two species are synonymous [13]; however, have demonstrated conclusively that the two are genetically separate.

In phenotypic appearance and molecular evidence [13] C. gariepinus is morphologically similar to $H$. longifilis and hence, it is reasonable to suggest that $H$. longifilis is related to the ancestor of $C$. gariepinus. Support to the above is based on the fact that the Malagarasi River, from where $H$. longifilis was obtained, and the Lake Victoria basin once belonged to the same catchment before the uplifting of the Tanzanian plateau in the Miocene period [14], and probably $H$. longifilis disappeared from Lake Victoria when the lake dried out [15]. Based on the external morphological relationship as observed in the present study C. liocephalus was found to be more close to C. gariepinus and possibly the two species shared the same ancestor, as were C. werneri and C. alluaudi [2]. Clariallabes petricola, the most anguilliform clariid in Lake Victoria possibly was the last to emerge in this deductive line of evolutionary relationships. This deduction is further supported by molecular evidence [13] and conforms to the orthogenic evolutionary theory (Figure 4), put forward by [16].

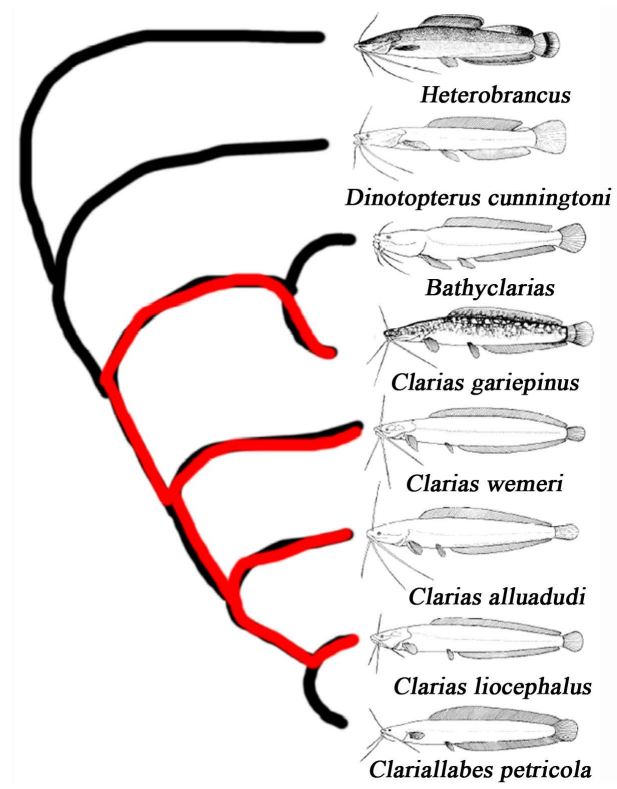

Figure 4. Morphological relationships among the clariid species-note the eel-like morphological progression. The red line depicts the specimen handled in this study. 


\section{Acknowledgements}

The author wishes to thank all those who made this work possible. Most important is the Lake Victoria Environment Management Project, University of Dar es Salaam subcomponent who financed this study. Tanzania Fisheries Research Institute (TAFIRI), Mwanza centre for provision of laboratory space.

\section{References}

[1] Cabuy, E., Adriaens, D., Verraes, W. and Teugels, G.G. (1999) Comparative Study on the Cranial Morphology of Gymnallabes typus (Siluriformes: Clariidae) and Their Less Anguilliform Relatives, Clariallabes melas and Clarias gariepinus. Journal of Morphology, 240, 169-194. http://dx.doi.org/10.1002/(SICI)1097-4687(199905)240:2<169::AID-JMOR7>3.0.CO;2-3

[2] Eccles, D.H. (1992) FAO Species Identification Sheets for Fishery Purposes. Field Guide to the Freshwater Fishes of Tanzania. UNDP Project URT/87/016, Rome.

[3] Alexander, R.M. (1965) Structure and Function in the Catfish. Journal of Zoology, 148, 88-152. http://dx.doi.org/10.1111/j.1469-7998.1966.tb02943.x

[4] Witte, F. and Van Densen, W.L.T. (1995) Fish Stock and Fisheries of Lake Victoria. A Handbook for Field Observation, Samara Publishing House. Samara House, Cardigan.

[5] Babik, W. and Rafinski, J. (2000) Morphometric Differentiation of the Moor Frog (Rana arvalis Nilss.) in Central Europe. Journal of Zoological Systematics and Evolutionary Research, 38, 239-247. http://dx.doi.org/10.1046/j.1439-0469.2000.384148.x

[6] Dresilign, E.D. (2003) The Small Barbs (Cyprinidae: Teleostei) of a Tropical Highland Lake (L. Tana, Ethiopia): Their Ecology and Potential for Fishery. Ph.D. Dissertation, Wageningen.

[7] Kappes, H. and Sinsch, U. (2002) Morphological Variation in Bosmina longirostris (O. F. Müller, 1785) (Crustacea: Cladocera): Consequence of Cyclomorphosis or Indication of Cryptic Species? Journal of Zoological Systematics and Evolutionary Research, 40, 113-122. http://dx.doi.org/10.1046/j.1439-0469.2002.00184.x

[8] Künzel, W., Breit, S. and Oppel, M. (2003) Morphometric Investigations of Breed-Specific Features in Feline Skulls and Considerations on Their Functional Implications. Anatomy, Histology and Embryology, 32, 218-223. http://dx.doi.org/10.1046/j.1439-0264.2003.00448.x

[9] Teugels, G.G. (1986) A Systematic Revision of the African Species of the Genus Clarias (Pisces; Clariidae). Annales Musee Royal de l'Afrique Centrale, 247, 1-199.

[10] Ling, N., Gleeson, D.M., Willis, K.J. and Binzegger, S.U. (2001) Creating and Destroying Species: The “New” Biodiversity and Evolutionarily Significant Units among New Zealand’s Galaxiid Fishes. Journal of Fish Biology, 59, 209-222.

[11] Skelton, P. (1993) A Complete Guide to the Freshwater Fishes of Southern Africa. Southern Book Publishers (Pty) Ltd., Halfway House.

[12] Agnese, J.F. and Teugels, G.G. (2005) Insight into the Phylogeny of African Clariidae (Teleostei: Siluriformes): Implications for Their Body Shape Evolution, Biogeography and Taxonomy. Molecular Phylogenetics and Evolution, 36, 546-553. http://dx.doi.org/10.1016/j.ympev.2005.03.028

[13] Mwita, C. and Nkwengulila, G. (2008) Molecular Phylogeny of the Clariid Fishes of Lake Victoria, Tanzania, Inferred from Cytochrome $b$ DNA Sequences. Journal of Fish Biology, 73, 1139-1148. http://dx.doi.org/10.1111/j.1095-8649.2008.01935.x

[14] Giddelo, C.S., Arndt, A.D. and Volckaert, F.A.M. (2002) Impact of Rifting and Hydrogeography on the Genetic Structure of Clarias gariepinus in Eastern Africa. Journal of Fish Biology, 60, 1252-1266. http://dx.doi.org/10.1111/j.1095-8649.2002.tb01718.x

[15] Johnson, T.C., Scholz, C.A., Talbot, M.R., Kelts, K., Ricketts, R.D., N’gobi, G., Beuning, K.R.M., Ssemmanda, I. and McGill, J.W. (1996) Late Pleistocene Desiccation of Lake Victoria and Rapid Evolution of Cichlid Fishes. Science, 273, 1091-1093. http://dx.doi.org/10.1126/science.273.5278.1091

[16] Agnese, J.F. and Teugels, G.G. (2001) Genetic Evidence for Monophyly of the Genus Heterobranchus and Paraphyly of the Genus Clarias (Siluriformes, Clariidae). Copeia, 2, 548-552. http://dx.doi.org/10.1643/0045-8511(2001)001[0548:GEFMOT]2.0.CO;2 
Scientific Research Publishing (SCIRP) is one of the largest Open Access journal publishers. It is currently publishing more than 200 open access, online, peer-reviewed journals covering a wide range of academic disciplines. SCIRP serves the worldwide academic communities and contributes to the progress and application of science with its publication.

Other selected journals from SCIRP are listed as below. Submit your manuscript to us via either submit@scirp.org or Online Submission Portal.
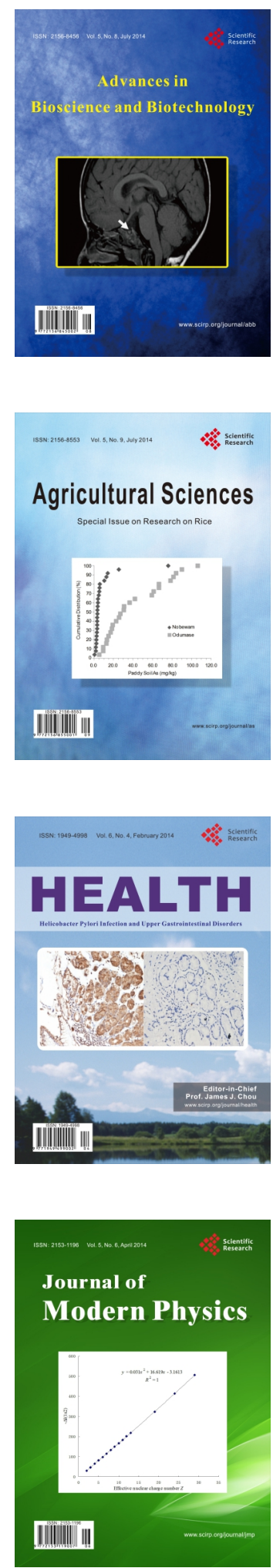
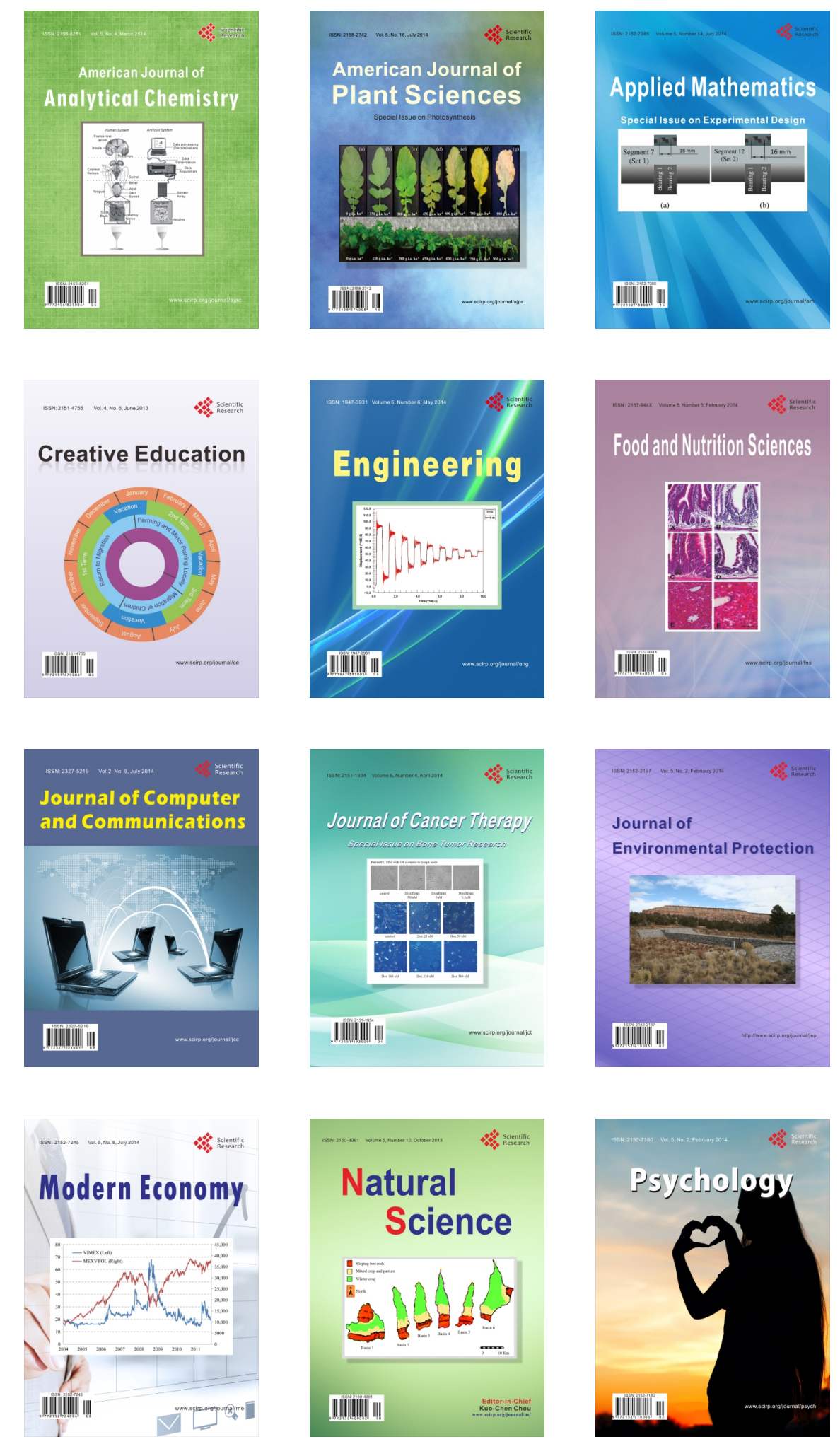